Ivan Arnautović

\title{
Theoretical aspects in the defining of mobbing (or bullying)
}

\begin{abstract}
In this article, the author presents a theoretical aspect of the definition of mobbing - sometimes called bullying - as a phenomenon related to the modern business organisation. Mobbing is a specific form of behaviour in the workplace where a supervisor, or colleagues, mistreat and humiliate another person in order to undermine his or her reputation and dignity. This ultimately poses a threat both to the mental and the physical health of the victim. Practice has shown that mobbing may also take place in the opposite direction, i.e. when employees abuse their supervisors. Today, we talk about mobbing with a lack of understanding of this complex phenomenon and regardless of its large workplace presence in its various forms including, among others, sexual harassment, ridicule and threats. The problems caused by, and the methods of the elimination of mobbing at work, together with discrimination as a cause of mobbing, can be solved only with knowledge and understanding of the theoretical aspects, while applying an interdisciplinary approach.
\end{abstract}

Keywords: mobbing, bullying, discrimination, harassment, dignity at work, human rights, UN conventions, legislative response, social partners, framework agreements, mobbing roles, mobbing consequences, mobbing phases, counteractive measures

\section{Introduction}

The problem of mobbing has been dealt with more thoroughly over the last two decades. Nevertheless, many people are not familiar with the term, or else they do not find it comprehensible and clear enough, even though mobbing is as old as human society. The desire of individuals to be in charge; the need to humiliate others; and jealousy, envy and hatred date back as far as human society, while the various pressures on people's moral, mental, physical and other types of integrity represent a very old category.

When we speak of the consequences of mobbing, what comes to mind usually are the victims of mobbing - employees who suffer terror and the psychological and physical consequences that manifest through a variety of symptoms, such as depression, anxiety, crying, a sense of de-personalisation, panic attacks, social isolation, emotional numbness and many more. However, the consequences are, in many respects, immense also for the organisation, with mobbing adding significantly to the cost base. The result is a communications disorder between employees and also an unhealthy work environment. 
Of course, mobbing also represents a potential source of industrial and social conflicts on a larger social scale. Mobbing can be referred to both as a symptom and as a consequence of permanently disturbed interpersonal relations in organisation where it appears.

\section{Theoretical framework}

Looking at mobbing as a phenomenon we cannot help but wonder at the animalistic roots of human beings - although animals are more 'fair', mostly because they use mobbing to preserve a species while humans do so to retain power and position.

From the moment when a number of living beings gather together, whether a herd of animals or a group of people, they instinctively seek to put themselves under the authority of the chief or leader. (Le Bon, 2007)

Unfortunately, this kind of animal instinct is also a characteristic of the human race. Therefore, this is a consequence of Darwin's understanding of the human being as a 'specific animal', while the following rule is applicable when speaking of mobbing:

A group is more than an individual. It is a faith that creative abilities of a group are bigger than the ones of a man. (Vukotić, 2011: 74)

Speaking of theories of instincts in the origin of aggressive behaviour, Freud's psychoanalytic theory is essential (Freud, 1962). In his theory, Freud explains the phenomenon of aggressive behaviour solely in terms of biological, inborn instinct. Aggression is an integral part of human affectivity and takes a significant place in personality development. It can be expressed both overtly and covertly. Freud also stated that:

The destiny of the horde has left indelible traces in the history of human heritage, moral and social organization. (Freud, 2006: 186)

The work of Alfred Adler is also crucial for a comprehensive understanding of human psychology - and also business psychology too. Adler's theory is based on two essential terms: 'striving for superiority' and 'the inferiority complex' (Adler, 2012).

From the perspective of the complex human psyche, Carl Gustav Jung provided a great contribution to science in 1914 when he diverged from Freud and psychoanalysis. The unconsciousness, for Jung, is not only a landfill site of bad instincts but also a source of wisdom. Besides the personal unconscious that comprises many complexes, inherited and super personality, the collective unconscious plays an important role in spiritual life (Stajn, 2007).

Regardless of the period when these theories were founded, which is at the beginning of the twentieth century, the problem of mobbing was not even then discussed, although psychological personality profiles, which were clearly defined in such theories, were directly connected to the personalities of mobbing victims and their perpetrators. 
The first scientific interpretation of mobbing was given by a Swedish psychologist of German origin, Professor Heinz Leymann, born on 17 July 1932. During the 1960s, Professor Leymann researched mobbing in schools where he noticed children's hostile behaviour. Later, in the 1980s, he noticed the same type of behaviour in the business environment and he started to research the problem more thoroughly. He was the first to use the term 'mobbing' to describe deviant behaviour in the workplace. He took the word mobbing from the etiology of Konrad Lorenz, who was born on 7 November 1903 in Vienna and who died on 27 February 1989, also in Vienna. Lorenz used the word 'mobbing' to describe animals' behaviour when they pick on one of their members, mark it as unwanted and start torturing it.

Professor Leymann is the author of an encyclopedia of mobbing in which he warned the global community about mobbing as a neglected, and tolerated, form of the violation of basic human rights that can be particularly harmful not only for the victim but also for the working collective. According to Professor Leymann, regardless of whether it takes place via vicious remarks, spying, slander or even threats and torture, the aim of every mobbing incident is the compromising of the integrity of an individual - his or her professional or social, but also private, life.

Professor Leymann may absolutely be seen as the founder of the theory of mobbing, but the first publication, and the first recognition, in this field was recorded in the book The Harassed Worker by Carroll Brodsky in 1976. The author observed employees affected by stress and presented several cases of psychological abuse. The book he wrote based on such observations shows cases that today we would call mobbing.

It is no coincidence that psychologists and psychiatrists dealt first with this type of behaviour derived from mobbing. Mobbing presents a clear picture of a psychological condition of both bullies and mobbing victims, as well as those who silently observe, unaware that the same thing may happen to them. In other words, mobbing, and successfully counteracting this harmful phenomenon, have their stronghold in the morality of an individual and of society. This is a reminder that, when we say human beings are conscious social beings, they are also at the same time a moral being, because the first two of these make no sense without the third.

\section{Types of mobbing}

As a phenomenon, mobbing is manifest in various forms and subtle nuances and is often difficult to recognise. This is the main obstacle to counteracting mobbing more efficiently. Therefore, careful analysis of the different forms of mobbing is of great importance so that they can be better recognised and identified and, ultimately, classified. Consequently, it is important to bear in mind the basic common factors of mobbing in general: these are an intention to bully, as well as the duration of mobbing; along with a systematic repetition of the actions that represent mobbing.

Analysing the models and the classification criteria, it can be concluded that, for the most part, they conform to a recognition that the essential features of mobbing can be summed up in two criteria (Žikić, 2010):

1. the identities of the perpetrator and the victim

2. what the motive is. 
Following the first criteria we may differentiate:

a) vertical mobbing

b) horizontal mobbing

And, following the second criteria, i.e. the mobbing motive, we may differentiate:

a) strategic mobbing

b) emotional mobbing

\section{Vertical mobbing}

Vertical mobbing is the most conspicuous form of mobbing, manifested through the psychological attacking of an employee by his or her supervisor. However, vertical mobbing can go the opposite way as well, in the case of a group of employees mobbing the supervisor.

\section{Horizontal mobbing}

Horizontal mobbing occurs among employees on the same level of the organisational hierarchy, i.e. when colleagues are harassing the one they have targeted. Horizontal mobbing most often appears as a result of the feeling of being put in jeopardy; or the rise of internal problems, tensions, jealousy or envy. In this situation, one of the colleagues is being chosen as a 'scapegoat' on whom the entire group releases its frustration and, at the same time, confirms its strength and capability.

\section{Strategic mobbing}

This is the case when the management of an organisation achieves a consensus on strategic harassment. The most usual form is the creation of lists of unwanted employees who have to be removed from the organisation through a set of deliberate moves. In the main, these are lists of employees to be laid-off without respect for their basic rights including as regards severance pay, systems for the purchase of additional service, etc.

\section{Emotional mobbing}

Emotional mobbing comes as a result of anger, jealousy, envy or antipathy towards the victim. The reasons for taking malicious actions are found in the personalities of both victims and abusers.

\section{Other sub-classifications of mobbing}

Today, we recognise many sub-types of mobbing, such as: silent/non-verbal mobbing; visible/verbal mobbing; e-mobbing; political mobbing; physical mobbing; indirect mobbing; etc.

Differing from visible forms of mobbing, silent mobbing is hidden and difficult to notice by the victim's peers. In today's period of modern technological development, e-mobbing is a widespread phenomenon. The sending of disturbing text messages and e-mails is just one of the ways that bullies reach their goals. Political mobbing is most often manifested in the discriminating treatment of political dissenters in the organisational environment. Basing action on employees' party affiliation is one of the usual 
ways in which political mobbing takes place. Physical mobbing is the basest form of harassment at work. This type of mobbing is a sub-type of visible mobbing. Indirect mobbing is less noticeable, since the victim is not exposed to direct, or overt, forms of harassment. Therefore, it is very often classified as a sub-type of silent mobbing.

\section{Protection of human rights and legislation concerning the prevention of mobbing}

Whereas recognition of the inherent dignity and of the equal and inalienable rights of all members of the human family is the foundation of freedom, justice and peace in the world... (Universal Declaration of Human Rights, 1948: 1)

The concept of human rights after the Second World War, as we can see from the Universal Declaration of Human Rights, is based on the inherent dignity of all and the recognition of their universal and inalienable character. Human rights are as old as human civilisation, since they derive from the dignity and value of every human being. The Magna Carta (1215), the first significant document in this field, sought to define human rights although it was focused only on some social classes. More than eight centuries passed between the Magna Carta and the Universal Declaration of Human Rights. Over that period, the mechanisms for the protection of human rights became more and more complex, extensive and diverse.

In addition to the Universal Declaration of Human Rights from 1948, the UN declared an International Covenant on Civil and Political Rights and an International Convention on Economic, Social and Cultural Rights, both from 1966 and operational from 1976. These three documents make up what we know today informally as the International Bill of Human Rights. Other important legal acts in the field of human rights are the European Convention on Human Rights (1950) and the European Social Charter (1961).

The International Covenant on Civil and Political Rights stipulated the establishment of a Human Rights Committee that would ensure the implementation of the norms established by the Covenant. The Vienna Declaration and the associated action programme, adopted by the World Conference on Human Rights in 1993, contain the modern interpretation of the original Declaration of Human Rights. The level of consensus on these conventions varies in terms of the number of countries that have ratified them and also in the number of those who have implemented them. The United Nations also established a list of entities, governed by the United Nations High Commissioner for Human Rights (UNHCHR), with the task of supervising and studying human rights.

Many non-governmental organisations - such as Amnesty International, Human Rights Watch, Freedom House, International Freedom of Expression Exchange and Anti-Slavery International - document the violation and abuse of human rights. The Victimology Society of Serbia, Stop Mobbing and the Republic Agency for the Peaceful Settlement of Labour Disputes are just some of the organisations that deal with the abuse of human rights in the workplace.

Nevertheless, the problem of mobbing is a growing issue that affects around twelve million employees in the European Union and, without support from the law, all efforts at combating it would be futile. 
In 1993, Sweden became the first country to incorporate regulations on protection against mobbing in its legal system. Soon afterwards, the Netherlands passed a Labour Law in 1994 which clearly prohibits any form of sexual harassment, psychological aggression and violence in the workplace. Subsequently, adequate laws were passed in Norway in 1994, in Denmark, Belgium and France in 2002, and in Canada in 2006, among others. In many countries, however, this topic is still unknown and the public remains uninformed. Montenegro and Serbia are among the countries that have passed a Law on Preventing Harassment at Work, also known as the Law on Mobbing.

Even so, practice has shown us that the legally-backed prevention of mobbing is important but that it is still not enough by itself. In order to prevent this phenomenon, it is necessary to have the goodwill of all the social partners - government, employers and trade unions; an awareness of the harmful influence of mobbing; and educational and democratic capacities.

The European Trade Union Confederation (ETUC / CES), the Confederation of European Business (Business Europe), the European Association of Craft, Small and Medium-Sized Enterprises (UEAPME) and the European Centre of Employers and Enterprises providing Public Services (CEEP) have signed an independent framework agreement on harassment and violence at work. The strong emphasis of this framework agreement is the prevention of mobbing, a result of the major efforts that the European Union has been putting in on preventing mobbing in recent years. Today, there are a number of regulations pertaining to this problem: for example, EU Council Directive $89 / 391 /$ EEC on the introduction of measures to encourage improvements in the safety and health of workers at work; and Directive 8/391 which raises the level of responsibility of employers in providing for the safety and health of workers at work in 'any aspect of the work'. Additionally, a European Parliament resolution on harassment in the workplace, A5-0283/2001, recommends that all EU member states supplement their existing legislation with a view to counteracting bullying and sexual harassment at work.

One of the important factors from the standpoint of the enactment of appropriate legislation regarding mobbing, as with any democratic, human, labour and social legislation on the whole, is the promotion of social dialogue. This comes from its definition as the most complex and comprehensive form of social partnership, through which the social partners may define their common interests at all levels of an organisation.

\section{Roles in a mobbing situation}

\section{Mobber, harasser or bully}

The simplest definition of a bully is an individual with a personality disorder who psychologically, morally or sexually harasses a victim with the aim of torturing, humiliating or forcing them to resign and leave the organisation. These are usually people who are eager for power but who cover up weakness and failure in other parts of their lives, i.e. family, marriage, education, etc, in order to 'prove' their importance by harassing the victim. Moral harassers are perverted people who create ambiguous situations, do not take responsibility and take advantage of naive victims. They are parasites 
on the victim's vitality and are prone to use a myriad other techniques to destroy and also gain reputation and power to the victim's disadvantage (Hirigoyen, 2003).

The characteristics of a bully's personality are the following - attention seeker, imitator, psychopath or sociopath (Kahalić, 2005: 12).

\section{Mobbing victim}

Recent research shows that anyone can be a victim of mobbing and that there are no typical victims. Bearing in mind that mobbing results from conflict and that, in many cases, it is barely noticeable, subtle and characterised by slow progression, it is not surprising that many are not aware that they are victims of mobbing. Instead, they relate all the strange episodes to stress and to being too engaged. In the beginning, the one that is abused has a hard time believing that he or she is a victim. Later on, they realise that everyone is against them, and start to reconsider, blaming themselves and experiencing their own incapability and devaluation.

Reactions which are characteristic of victims are the following:

- initial self-blame - 'am I responsible for this situation? where did I go wrong?'

- loneliness - the victim does not speak of the problem to family or friends, mostly because of the fear of 'double mobbing'

- personal devaluation - 'I am not able to fit in', 'I cannot solve the problem because I am incapable and worth less than zero'.

Those who seek to block and eliminate mobbing are characteristic of strong and very intelligent people who are aware of mobbing. They use all legal means at their disposal, as well as psychological and media resources to draw public attention.

\section{Support group}

Mobbing begins with conflict in the broadest sense of the word: a one-on-one conflict (between the bully and the victim). However, over time, the number of participants increases and leads to polarised relations between employees. On the one side, there is a victim as a lonely individual; while, on the other, there is the majority of employees, or even all of them. This is precisely the group that represents a support group for the bully and it is formed for the most part not because it agrees with the bully but out of fear of becoming a victim.

\section{Consequences of mobbing}

\section{Consequences for society}

Mobbing affects the whole of society. Having the productivity of an employee lowered by mobbing influences the overall productivity of the organisation as a whole which, ultimately, leads to decreased productivity at the level of the national economy. Its influence is also perceived through an increase in unemployment and the pay-out of unemployment benefits. Medical treatment and rehabilitation costs are also rising, as well as sickness pay. The healthcare system focuses on the condition of sickness, not on the condition of health. Mobbing also leads to an increase in the number of retirements, in particular an increased number of early and ill-health retirements. 


\section{Consequences for the organisation}

The effects of mobbing are also immense for an organisation in many respects: mobbing leads to a large escalation in costs due to decreased productivity and additional expenses. Lay-offs and the dismissal of employees are frequent and, therefore, the adjustment period required for new employees also becomes a problem. Additionally, decreased motivation and a lower readiness to work are evident. Statistics in Germany have shown that the cost of each victim of mobbing to an organisation is around $€ 75000$ per year.

It has been proven that it is more cost-effective for companies to provide professional rehabilitation, even the most expensive, rather than to let employees use sick leave without a successful final resolution.

\section{Consequences for health}

Self-incrimination, solitude and self-abasement are the first outcomes of the psychological and physical condition of the mobbing victim, followed by a state of disturbance. This is the earliest stage when people of lower psycho-physical strength can completely deteriorate, isolating themselves from family and social life or becoming aggressive not only towards themselves but towards others, too. At this stage, difficulties start to appear: for example, apathy; inexplicable fatigue; exhaustion; withdrawal; and also demoralisation due to the constant humiliation, disparaging, mocking and rejection. Other symptoms are a loss of joy and pleasure in everyday activities and also tension.

Symptoms following mobbing attacks are depression, anxiety, crying, feeling depersonalised, panic attacks, social isolation, emotional numbness, headaches, sleeping disorders, vertigo, digestion problems, hypertension, hyperglycaemia, heart issues and skin changes. It is proven that mobbing affects behaviour through aggression, passiveness and increased use of medication, as well as higher consumption of alcohol and cigarettes, etc.

\section{Phases in the development of mobbing}

\section{Critical incidents}

This phase of mobbing is connected to the appearance of conflict and then its escalation. All of these lead to the deterioration in interpersonal relations which forms the basis of the development of mobbing. The original conflict can even have become forgotten, but aggressive tendencies grow more dangerous and more sharp as regards the victim-to-be. Critical incidents last for a very short time before very quickly moving on to the next phase - the phase of stigmatising. The main characteristic of this phase is that, formally, mobbing still does not exist.

\section{Mobbing and stigmatising}

In the literature, the phase of mobbing and stigmatising is also often called the phase of 'targeted mobbing' or the 'phase of aggression escalation'. Characteristic of this phase is the situation where the victim is singled out and stigmatised through the es- 
calation of the suppressed aggression of the bully into forms of psychological terror. The victim begins to lose self-esteem and feels less valuable.

\section{Human resource management}

At one point, mobbing reaches a level at which it can no longer be hidden. Once it becomes visible by management, it becomes official. The victim is already greatly stigmatised and isolated, and constantly harassed. Therefore, the situation of a so-called 'scapegoat' is created, which is also another name for this phase. Here we talk about a total stigmatising of the victim as a 'whipping post' for all the faults in the organisation.

\section{Wrong diagnosis}

Mobbing is very difficult to detect, and so it is frequently the case that a person exposed to mobbing asks for help from a psychiatrist or a psychologist who delivers a wrong diagnosis because of a lack of experience in studying social relations at work. Psychiatrists or psychologists tend to evaluate a person on the basis of personality characteristics which, in this case, is the wrong approach. A wrong diagnosis can be manifested as paranoia, manic depression, personality disorder, etc. All of this can also have a hugely negative effect on the lives and the future careers of mobbing victims.

\section{Exclusion}

Exclusion is considered to be the final phase of mobbing, i.e. temporary suspension or even exclusion from a workplace - being dismissed from an organisation due to the victim's weakness at dealing with the problem. It is noticed that, in this phase, serious disorders can occur, resulting in the victim seeking medical or psychological help. Exclusion is also referred to as the phase of the victim's final breakdown when the victim, under lasting pressure and stress, leaves the organisation.

\section{Counteracting mobbing}

When choosing measures to counteract mobbing, it is essential to determine which phase of mobbing is in play. This is worth emphasising since different measures are available depending on whether mobbing just needs to be stopped or whether the rehabilitation of the victim is also necessary.

Taking into consideration the complexity of the problem, measures which may be taken to counteract mobbing incidences may include not only the involvement of managerial structures but also professionals from different fields connected to this problem, such as sociologists, psychologists, psychiatrists, occupational health professionals, legal experts and many others.

The problem should primarily be approached from the aspect of prevention as well as from the early intervention of management. In the case of where consequences have resulted, professional rehabilitation and a resort to legislation may also be useful parts of the toolbox. 


\section{Conclusion}

No matter how frequently used, the terms mobbing and bully still remain substantially unrecognisable phenomena. In most cases, the victims of mobbing are left on their own to try to find a way out of their crisis by themselves, without adequate protection. This is the very result of an insufficient education on mobbing.

Mobbing has to be analysed through the lens of corporate social responsibility, which represents a way of dealing with those issues which have a social and cultural character, including the management of human resources and health protection at work. In other words, those issues which are not directly connected to business goals but which are related to their achievement. Responsible competitiveness is a frequent second goal of business, so the interest of the employer represents a way in which the business community relates to social and environmental issues. Meanwhile, the financial dimension of harassment at work is the common interest of all factors involved in business - of employees and society at large as well as employers.

Counteracting mobbing at the social level is of great importance. The means for reaching this goal can be the media - both printed and electronic - and also efficient legislation.

When it comes to mobbing, public representation and public advocacy are essential, mostly through a process of drawing the attention of the whole community to the importance of the problem and also in directing the community towards reaching the appropriate to decisions to counteract mobbing.

The precondition for this is an improvement of the instruments of democratic society, i.e. in strengthening the roles and influence of civil society organisations. Furthermore, this implies the education of management and employees in the area of the workplace and the economic and social rights of workers, as well as a raising of the awareness of every individual that he or she is a free human being who has to defend their own freedom and dignity.

What imposes itself here as a rational conclusion is that counteracting mobbing has yet to come. There is no employed individual today who has not experienced at least once some sort of discrimination at work, over a longer or a shorter period of time. Recently, some positive moves have been more evident, especially regarding the sharing of information about mobbing and also in enacting pieces of legislation in response.

The current world economic crisis and high unemployment rate go in favour of an increase in mobbing. Employees are afraid of having difficulties in finding a new job and this causes mobbing to remain hidden. On the other hand, health is priceless and, therefore, we are left to determine where are our own limits and what we are prepared to put up with for the sake of not losing a job. Of course, these questions are not easy to answer. Accordingly, we are left to think about them and to search every day for solutions and answers. 


\section{References}

Adler, Alfred (2012) Poznavanje čoveka Dereta: Beograd.

Baltazarević, Vesna (2007) Mobing komunikacija na četiri noge MN: Pančevo.

Barron, $\mathrm{O}$ (2003) Why workplace bullying and violence are different Willan Publishing.

Daniel, Barbara (2004) Workplace bullying Florida State University: Florida.

Davenport, Noah, Ruth Schwartz and Elliott Gail (1999) Mobbing: Emotional Abuse in the American Workplace Civil Society Publishing.

Freud, Sigmund (2006) Psihologija mase i analiza ega Fedon: Beograd.

Fukujama, Francis (1997) Sudar kultura Poverenje Zavod za udžbenike: Beograd.

Glajk, Džejms (2001) Haos Narodna knjiga: Beograd.

Hallowell, Edward (2007) Managing stress Harvard Business Press.

Hirigoyen, Marie France (2003) Moralno zlostavljanje; perverzno nasilje u svakodnevici AGM: Zagreb.

Kare, Kristof (2006) Izaći iz konflikta sa drugima MK: Beograd.

Kahalić, Ivica (2005) Zločin bez kazne Epoha br. 46.

Kosanović, Rajko (2008) Mobing - psihološki teror na radu Radnička štampa: Beograd.

Kostelić-Martić, Andreja (2005) Mobing: psihičko maltretiranje na radnom mestu Školska knjiga: Zagreb.

Le Bon, Gustav (2007) Psihologija gomila Gradac: Beograd.

Leymann, H (1998) The Mobbing Encyclopedia.

Lubarda, Branko (2007) Radno pravo Evropske unije CID: Podgorica.

Marinković, D (2009) Mobing kao vid prinudnog i ropskog rada Ekonomski vidici DEB: Beograd.

Marinković, D (2005) Industrijski odnosi Megatrend University: Beograd.

Maslow, A. H (1982) Motivacija i ličnost Nolit: Beograd.

Osif, Bonnie (2008) Stress management Pennsylvania State University.

Seydl, Christoph (2006) Workplace Mobbing/Bullying: A Deviant Conflict Redirection Johannes Kepler University, Linz, Austria.

Williams, Stephen and Lesley Cooper (2002) Managing Workplace Stress Wiley: Chichester.

Stajn, Marej (2007) Jungova mapa duše Laguna: Beograd.

Sutton, Robert (2010) The No Asshole Rule: Building a Civilized Workplace and Surviving One That Isn't Business Plus: New York.

United Nations (1948) Univerzalna deklaracija o pravima čoveka. 
Vuković, Branko (2009) Mobing IP Logos Art: Beograd.

Vuković, Branko (2009) Šta je stres IP Logos Art: Beograd.

Vukotić, Veselin (2011) Istorija budućnosti Media sistem i CID: Podgorica.

Žikić, Srđan (2010) Mobing Zadužbina Andrejević: Beograd. 